\title{
Natural Surfactant Instilled in Premature Lambs Increases Lung Volume and Improves Ventilation Homogeneity within Five Minutes
}

\author{
C. VILSTRUP, D. GOMMERS, J. A. H. BOS, B. LACHMANN, O. WERNER, AND A. LARSSON \\ Department of Anesthesia and Intensive Care, University Hospital, S-221 85 Lund, Sweden [C.V., O.W., A.L.], \\ and Department of Anesthesiology, Erasmus University, Rotterdam, The Netherlands [D.G., J.A.H.B., B.L.]
}

\begin{abstract}
The immediate effects on lung volume, ventilation homogeneity, and lung mechanics of tracheal instillation of surfactant were studied in premature lambs, gestational age 120-122 d, with respiratory distress syndrome. Six lambs received surfactant by tracheal instillation 25 min after delivery by cesarean section; five received only vehicle and served as controls. The lambs were studied for $60 \mathrm{~min}$ thereafter. Functional residual capacity was measured with a computerized tracer gas washin-washout technique using sulfur hexafluoride as tracer gas. A measure of ventilation inhomogeneity (pulmonary clearance delay) was also calculated from the washout curves. Pressurevolume curves were studied with an interrupter technique during deflation of the lungs from an airway pressure of 30 $\mathrm{cm} \mathrm{H}_{2} \mathrm{O}$. In the surfactant group, arterial oxygenation and ventilation homogeneity improved within 5 min of giving surfactant; major increases in functional residual capacity, vital capacity, and compliance occurred within 5 to $20 \mathrm{~min}$ and were followed by gradual further improvements. The pressure-volume curve thus increased in amplitude and became steeper, but the lung volumes at various inflation pressures, and compliance, remained constant when expressed as fractions of total lung capacity volume. It is concluded that an improvement in lung volume, respiratory mechanics, and ventilation homogeneity occurs very soon after surfactant instillation and that there is a phase of successive further improvement over the next hour. Although the amplitude of the pressure-volume curve varied considerably, its basic shape varied little. This suggests that opening of new distal airways by surfactant predominated over changes in the mechanics of already aerated lung regions. (Pediatr Res 32: 595-599, 1992)
\end{abstract}

\section{Abbreviations}

$C_{\text {dyn, }}$ dynamic compliance

TLC, total lung capacity volume

PEEP, positive end-expiratory pressure

FRC, functional residual capacity

PCD, pulmonary clearance delay

$P-V$, pressure-volume

$\mathrm{SF}_{6}$, sulfur hexafluoride

$V_{T}$, tidal volume

$\mathrm{C}_{\max }$, maximal static lung-thorax compliance

RDS, respiratory distress syndrome

i.m., intramuscularly

Received January 23, 1992; accepted May 21, 1992

Correspondence: Dr. Carsten Vilstrup, Department of Anesthesia and Intensive Care, University Hospital, S-221 85 Lund, Sweden.

Supported by grants from the Swedish Society of Medicine, the Swedish Medical Research Council, Grant No. B92-17X-09506-02B, AB AGA, the Medical Faculty at the University of Lund, and the Dutch Foundation for Medical Research
(SFMO).
$\mathrm{PaO}_{2}$, arterial oxygen tension

$\mathrm{PaCO}_{2}$, arterial carbon dioxide tension

In infants, the effects of surfactant treatment on lung mechanics have mainly been expressed as changes in $C_{d y n}$, which has failed to show any improvement when measured within the first hour $(1,2)$. To better clarify the immediate effects of surfactant instillation on lung volume and lung mechanics, we measured FRC and TLC, and also the elastic recoil of the total respiratory system during interrupted expiration from TLC. Ventilation homogeneity was studied by tracer gas washout. The measurements were done during the first hour after surfactant treatment of premature lambs in respiratory failure.

\section{MATERIALS AND METHODS}

Preparation of animals. The study was approved by the Animal Investigations Committee of the Erasmus University, Rotterdam. Eleven lambs (gestational age between 120 and $122 \mathrm{~d}$, body weight $1-3 \mathrm{~kg}$ ) were delivered via hysterotomy. Before delivery, the lambs were randomly assigned to two groups; one group received surfactant $(n=6)$ and the other received the vehicle $(n$ $=5$ ). Nine date-mated pregnant ewes, two with twins, previously uninstrumented, were premedicated with ketamine i.m. (1200 $\mathrm{mg}$ ) and atropine sulfate i.m. $(2.4 \mathrm{mg})$. Anesthesia was induced with thiopental i.v. ( $3 \mathrm{mg} / \mathrm{kg})$, the trachea was intubated, and the lungs were ventilated with $100 \% \mathrm{O}_{2}$. Anesthesia was maintained with $2 \%$ enflurane and $70 \% \mathrm{~N}_{2} \mathrm{O}$ in $\mathrm{O}_{2}$. Pancuronium bromide i.v. $(0.1 \mathrm{mg} / \mathrm{kg})$ was used for muscle relaxation. Hysterotomy was performed and the lamb was delivered.

The lamb was wiped dry, weighed, and placed supine on a heating blanket and under a heating lamp. The body temperature was kept around $37^{\circ} \mathrm{C}$ during the experiment. A midpoint tracheostomy was done under local anesthesia $(3 \mathrm{~mL}$ of $4 \%$ lidocaine s.c.), and an uncuffed, smoothly fitting endotracheal tube was inserted. Lung fluid was not aspirated, but varying amounts of lung fluid were lost during the tracheotomy. The tracheal seal was ascertained by comparing the inspiratory and expiratory $V_{T}$ and by observing that no decrease in airway pressure occurred during a prolonged inspiratory pause. About $10 \mathrm{~min}$ after delivery, the animals were ventilated with pressure-control using a Servo 900C (Siemens Elema, Stockholm, Sweden) at the following settings: rate $60 / \mathrm{min}$; positive inspiratory pressure $35 \mathrm{~cm}$ $\mathrm{H}_{2} \mathrm{O}$; PEEP $4 \mathrm{~cm} \mathrm{H} \mathrm{H}_{2} \mathrm{O}$; inspiratory time $33 \%$, and end-inspiratory pause $5 \%$ of the ventilatory cycle. The inspiratory oxygen fraction was 1.0. Anesthesia was induced with sodium pentobarbital $(50 \mathrm{mg} / \mathrm{kg})$ i.v. and maintained by intermittent intraperitoneal injection of the same drug $(5 \mathrm{mg} / \mathrm{kg} / \mathrm{h})$. For muscle relaxation, pancuronium bromide $(0.3 \mathrm{mg} / \mathrm{kg}$ i.m. $)$ was given. The left 
carotid artery was cannulated for continuous monitoring of arterial pressure and for blood sampling. A catheter was inserted in the right jugular vein for fluid administration. Maintenance fluid consisted of $5 \mathrm{~mL} / \mathrm{kg} / \mathrm{h}$ of a $2.5 \%$ glucose solution. Five $\mathrm{mL}$ of sodium bicarbonate were given when base excess was less than $-5 \mathrm{mEq} / \mathrm{L}$. About $25 \mathrm{~min}$ after delivery, i.e. about $15 \mathrm{~min}$ after start of mechanical ventilation, the animals in the treatment group received $150 \mathrm{mg} / \mathrm{kg}$ surfactant dissolved in hypotonic saline $(0.6 \% \mathrm{NaCl})$ intratracheally. This dose has been found to be optimal for this surfactant preparation; it prevents fast deterioration of arterial oxygenation, which is a sign that the amount of surfactant is not sufficient. The animals in the control group received the same amount of hypotonic saline. Except in one lamb, the experiment was concluded $60 \mathrm{~min}$ after surfactant or saline instillation and the animal was killed with an overdose of thiopental and potassium chloride i.v.

Surfactant. The surfactant used in this study was a natural surfactant isolated from bovine lungs in basically the same way as previously described (3). It consists of approximately $83 \%$ phospholipids, and $1 \%$ hydrophobic proteins (SP-B and SP-C), the remainder being other lipids such as cholesterol, glyceride, and FFA. There is no SP-A in this surfactant preparation. The freeze-dried preparation was resuspended in a $0.6 \% \mathrm{NaCl}$ solution to a total concentration of $50 \mathrm{mg}$ phospholipids/mL, warmed to body temperature, and instilled in the trachea with a syringe attached to the endotracheal tube.

Measurements. Measurements of FRC and $\mathrm{C}_{\mathrm{dyn}}$ were started when the animal was connected to the ventilator and repeated every 2-10 min until $60 \mathrm{~min}$ after the instillation. Between 16 and $20 \mathrm{FRC}$ measurements were made in each animal. PCD was calculated before and $5,15,30,45$, and $60 \mathrm{~min}$ after the endotracheal instillation. Static P.V curves were obtained just before and 20 and 60 min after the endotracheal instillation. $\mathrm{PaO}_{2}$ and $\mathrm{PaCO}_{2}$ were analyzed immediately after drawing the sample on an ABL330 (Radiometer, Copenhagen, Denmark) 5 min before instillation and at $5,15,30,45$, and $60 \mathrm{~min}$ after instillation.

FRC was measured with a computerized multiple breath washin-washout method using $\mathrm{SF}_{6}$ as tracer gas. The method has been described previously for studies of FRC and gas washout in adults, children, and small neonates (4-6). In brief, the components of the system (Fig. 1) included a computer (PDP 11/23, Digital Equipment Corp., Marlboro, MA), a ventilator (Servo 900C, Siemens-Elema), electromagnetic inspiratory and expiratory auxiliary valves (360P0121, Neptune Research, Maplewood, $\mathrm{NJ})$, and inspiratory and expiratory heated pneumotachographs (Fleisch no. 00, Lausanne, Switzerland; linearity flow range $=0$ $100 \mathrm{~mL} \cdot \mathrm{s}^{-1}$ ) with differential pressure transducers (MP 45-1$871,< \pm 2.5 \mathrm{~cm} \mathrm{H}_{2} \mathrm{O}$; Validyne, Northridge, CA). The tracer gas concentration was measured with an infrared analyzer (7). The transducer of the analyzer was placed over a cuvette with windows near the $\mathrm{T}$-piece in the expiratory part of the ventilator tubings. $\mathrm{SF}_{6}$ was washed in until the alveolar concentration was about $1.5 \%$. $\mathrm{SF}_{6}$ washout was continued until the concentration was less than $0.01 \%$. The amount of $\mathrm{SF}_{6}$ left in the lungs was calculated assuming the final part of washout was monoexponential. Signals representing expired flow and $\mathrm{SF}_{6}$ concentration were fed into the computer, which calculated FRC as the value of $\mathrm{SF}_{6}$ washed out plus the amount left in the lungs at end of washout divided by the alveolar concentration at end of washin. Apparatus dead space $(0.6 \mathrm{~mL})$ was subtracted from the obtained FRC value. The volume of the tubing between the auxiliary valves, including the bar of the $\mathrm{T}$-piece, was $0.8 \mathrm{~mL}$.

$\mathrm{PCD}$ was calculated from the $\mathrm{SF}_{6}$ washout curves as described by Fowler et al. (8) but with the modification by Bouhuys et al. (9), i.e. end-tidal concentration was used instead of mean expired concentration. The index compares the average time a tracer gas molecule remains in the lungs ( $\mathrm{T} 1$ ) with the average time a tracer gas molecule would remain in an uniformly ventilated lung with the same FRC and series dead space, ventilated with the same $\mathrm{V}_{\mathrm{T}}$, before being expired (T2). PCD was obtained from the

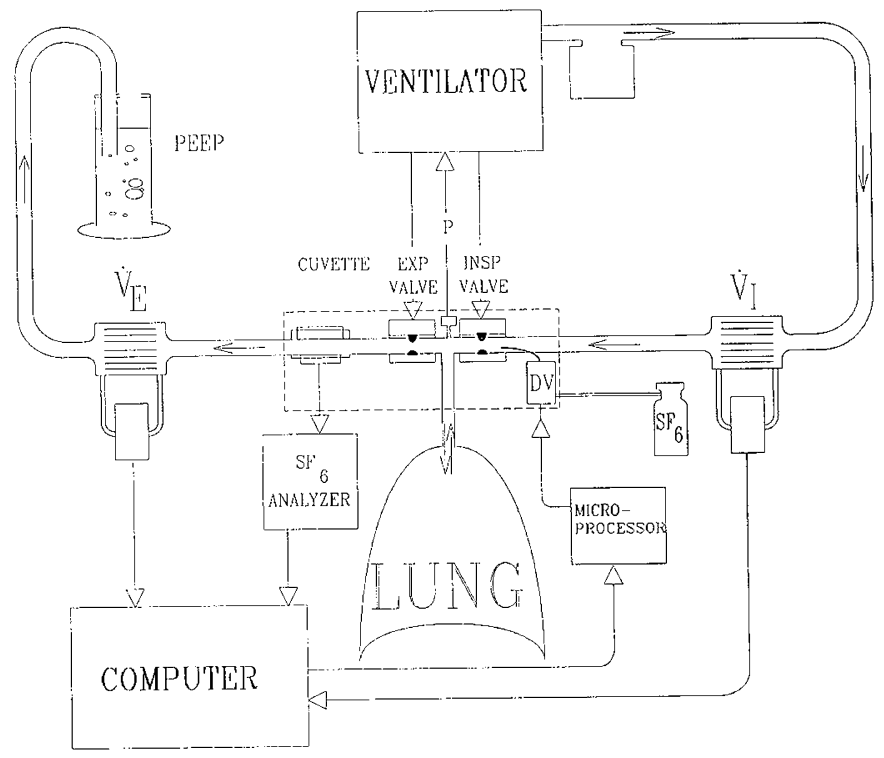

Fig. 1. The FRC measurement system. $\dot{V}_{I}$ and $\dot{V}_{E}$ represent the inspiratory and expiratory flow meter, respectively. $D V$, dispensing valve for $\mathrm{SF}_{6} . P$, signal from pressure transducer. The apparatus dead space was $0.6 \mathrm{~mL}$. Oscillation of gas between the inspiratory and expiratory limbs, which could disturb the assessment of flow from/to the patient, was prevented by placing auxiliary inspiratory and expiratory valves close to the $T$-piece. The equipment inside the interrupted frame was enclosed in a $8 \times 10 \times 16 \mathrm{~cm}$ box. The arrows indicate direction of flow in the measurement circuit. The unfilled arrowheads indicate flow of information.

following formula: $\mathrm{PCD}=100 \times(\mathrm{T} 1-\mathrm{T} 2) / \mathrm{T} 1$. The average time a molecule remained in the lungs (i.e. the average time of clearing the lungs) was calculated from the $\mathrm{SF}_{6}$ washout curve. The calculation of PCD was done with an interactive computer program (4) that approximated the curve as the sum of exponentially decaying functions: the computer plotted the washout curve semilogarithmically, and the user indicated how lines should be drawn to get the exponential curve components. The "peel-off" method was used, i.e. the slowest component was first identified and subtracted and the plot was then redrawn to identify the remaining component (or, occasionally, components). In all of the lambs, an adequate approximation of the curve was achieved with two components.

$\mathrm{C}_{\text {dyn }}$ was calculated as $\mathrm{V}_{\mathrm{T}} /(\mathrm{PIP}$ - PEEP) where PIP is the positive inspiratory pressure. The end-inspiratory and end-expiratory flow were nearly zero. The airway pressures at these points were therefore close to the corresponding alveolar pressures.

Static P-V curves were obtained by an occlusion technique previously used for measuring breath-by-breath compliance within the $V_{T}(10)$. The technique was modified for neonatal use and computerized. After replacing the FRC system with the P-V measurement system (Fig. 2) (via a slide valve), the lungs were inflated by a syringe to an airway pressure of about $35 \mathrm{~cm} \mathrm{H} \mathrm{H}_{2} \mathrm{O}$, which was maintained for at least $1 \mathrm{~s}$. During the following passive deflation to $0 \mathrm{~cm} \mathrm{H}_{2} \mathrm{O}$ of airway pressure, the expired flow was interrupted for $80 \mathrm{~ms}$ every $160 \mathrm{~ms}$ by a computergoverned electromagnetic occluder (Harting 08300320120 , Siemens Elema) placed close to the endotracheal tube. The airway pressure was measured with a pressure transducer (SCX01DN, SenSym, Rugby, UK) at the end of each occlusion and was assumed to equal the alveolar pressure. The flow signal was obtained by a Fleisch pneumotachograph no. 00 and a differential pressure transducer (MP-45-1-871, Validyne). The computer integrated the flow signal and calculated the volumes exhaled between occlusions. After completion of the maneuver, the P-V curve was plotted by an X-Y writer (HP 7575A) and data were stored on a computer disc. To obtain estimates of the 
WATER

\section{MANOMETER}

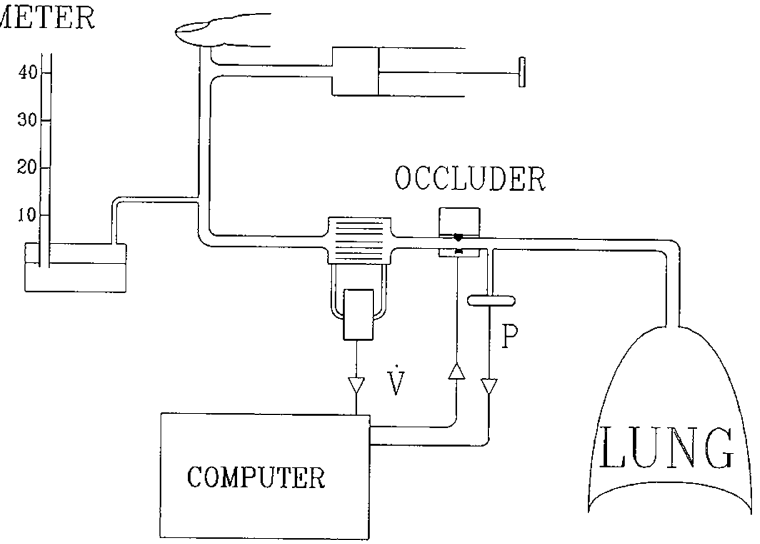

Fig. 2. The system for obtaining the P-V curves. The arrows indicate flow of information. $P$, pressure signal; $\dot{V}$, flow signal.

Table 1. Values (mean $\pm S D$ ) obtained before instillation of surfactant or vehicle*

\begin{tabular}{lcc}
\hline & Treatment group & Control group \\
\hline$n$ & 6 & 5 \\
Body weight $(\mathrm{kg})$ & $2.5 \pm 0.9$ & $2.1 \pm 0.9$ \\
$\mathrm{SAP}(\mathrm{mm} \mathrm{Hg})$ & $55 \pm 8$ & $50 \pm 12$ \\
$\mathrm{FRC}(\mathrm{mL} / \mathrm{kg})$ & $4.4 \pm 2.0$ & $3.2 \pm 2.4$ \\
$\mathrm{PCD}(\%)$ & $115 \pm 97.5$ & $92.1 \pm 65.4$ \\
$\mathrm{C}_{\mathrm{dyn}}\left(\mathrm{mL} \mathrm{cm} \mathrm{H} \mathrm{O}^{-1} \cdot \mathrm{kg}^{-1}\right)$ & $0.09 \pm 0.03$ & $0.09 \pm 0.03$ \\
$\mathrm{C}_{\max }\left(\mathrm{mL} \mathrm{cm} \mathrm{H} \mathrm{O}^{-1} \cdot \mathrm{kg}^{-1}\right)$ & $0.6 \pm 0.4$ & $0.5 \pm 0.3$ \\
$\mathrm{PO}_{2}(\mathrm{kPa})$ & $4.9 \pm 4.5$ & $5.0 \pm 3.2$ \\
$\mathrm{PCO}_{2}(\mathrm{kPa})$ & $12.8 \pm 1.8$ & $14.2 \pm 1.7$ \\
$\mathrm{pH}$ & $6.87 \pm 0.04$ & $6.85 \pm 0.05$ \\
\hline
\end{tabular}

* There were no significant differences between the groups. SAP, systolic arterial blood pressure.

absolute lung volumes at different airway pressures, lung volume curves were presented by the computer, assuming that FRC with $4 \mathrm{~cm} \mathrm{H}_{2} \mathrm{O}$ of PEEP, measured during controlled ventilation, was the same as the lung volume at $4 \mathrm{~cm} \mathrm{H}_{2} \mathrm{O}$ of airway pressure during the P-V maneuver. The $C_{\max }$ was the slope of the steepest part of the P-V curve.

Calibration. The flow signal was calibrated daily with $\mathrm{O}_{2}$ using a $50-\mathrm{mL}$ syringe before each set of measurements. The airway pressure was calibrated against a water manometer. All volumes were converted to body temperature and pressure of water vapor, saturated gas by multiplying by 1.09 .

Statistics. The Mann-Whitney two-tailed test for unpaired samples was used for between-group comparison. Within group variability was tested with two-way analysis of variance. Differences between individual measurement stages within groups were assessed with a test that compensated for multiple comparison (Student-Newman-Keuls). Coefficients of linear correlation between various measures were also obtained. Statistical significance was accepted as $p<0.05$. All data are reported as mean \pm $\mathrm{SD}$ or as otherwise indicated.

\section{RESULTS}

Data obtained before the instillation (after 10 min of mechanical ventilation) are given in Table 1 . There were no significant differences between the two groups. The blood gases indicated the severity of the respiratory failure. All lambs in the treatment group and two in the control group survived the experimental period.

FRC at $4 \mathrm{~cm} \mathrm{H}_{2} \mathrm{O}$ of PEEP (Fig. 3) increased from $4.4 \pm 2.0$ $\mathrm{mL} / \mathrm{kg}$ when measured 5 min before surfactant to $7.5 \pm 2.8 \mathrm{~mL} /$ $\mathrm{kg} 5 \mathrm{~min}$ after surfactant $(p<0.05), 9.5 \pm 3.3 \mathrm{~mL} / \mathrm{kg}$ at $15 \mathrm{~min}$, $12.4 \pm 2.9 \mathrm{~mL}$ at $30 \mathrm{~min}$, and $12.2 \pm 3.2 \mathrm{~mL}$ at $45 \mathrm{~min}$. It was
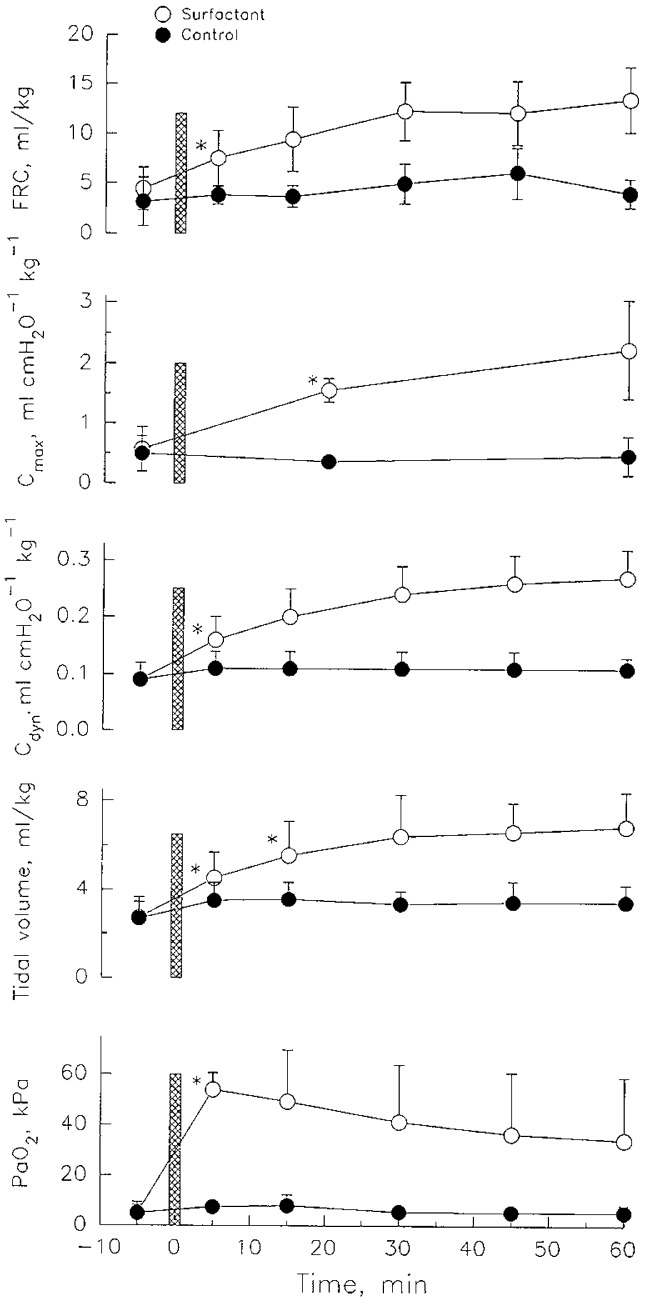

Fig. 3. FRC, $C_{\max }$ (see text), $C_{d y n}$, and $V_{r}$ per kg body weight and $\mathrm{PaO}_{2}$ in six surfactant-treated lambs and five controls (mean $\pm \mathrm{SD}$ ). In the treatment group, $F$ values (with $d f$ as subscripts) obtained by twoway analysis of variance were $14.1_{5}$ for $\mathrm{FRC}, 25.5_{2}$ for $\mathrm{C}_{\max }, 36.0_{5}$ for $\mathrm{C}_{\mathrm{dyn}}, 26.0_{5}$ for $\mathrm{V}_{\mathrm{T}}$, and $13.0_{5}$ for $\mathrm{PaO}_{2}$. Corresponding $p$ values were always less than 0.01 . $^{*}$, Significant change in relation to preceding measurement $(p<0.05)$.

$13.6 \pm 3.3 \mathrm{~mL} / \mathrm{kg}$ at $60 \mathrm{~min}$ after the instillation. Expressing FRC as a percentage of the value $60 \mathrm{~min}$ after surfactant gave a mean of $33 \% 5 \mathrm{~min}$ before surfactant, $55 \% 5 \mathrm{~min}$ after surfactant, $70 \%$ at $15 \mathrm{~min}, 91 \%$ at $30 \mathrm{~min}$, and $90 \%$ at $45 \mathrm{~min}$ after surfactant. PCD (Fig. 4) improved significantly $(p<0.05)$ after surfactant. No significant changes in FRC or PCD were noted in the control group.

$\mathrm{C}_{\mathrm{dyn}}$ (Fig. 3) increased $(p<0.05)$ in the treatment group concomitantly with the increase in FRC and in $V_{\mathrm{T}}$ (Fig. 3). $\mathrm{C}_{\mathrm{dyn}}$ was closely correlated to FRC $(r=0.94, p<0.01)$. The major change in $\mathrm{C}_{\mathrm{dyn}}$ occurred during the first 15 min after surfactant. No change was found in the control group.

After surfactant, the P-V curve (Fig. 5) shifted upward at all inflation pressures. Most of the change occurred during the first $20 \mathrm{~min}$, but there was a further upward shift also between 20 and $60 \mathrm{~min}$. The shift in the $\mathrm{P}-\mathrm{V}$ curves was reflected in a significant $(p<0.05)$ increase in $\mathrm{C}_{\max }$ (Fig. 3). In contrast, the ratio between lung volume at various inflation pressures and TLC (Table 2) did not change significantly, nor did specific compliance $\left(\mathrm{C}_{\mathrm{dyn}} / \mathrm{TLC}\right.$ or $\left.\mathrm{C}_{\max } / \mathrm{TLC}\right) . \mathrm{PaO}_{2}$ (Fig. 3) increased $(p$ $<0.05)$ immediately after surfactant instillation from $4.9 \pm 4.5$ $\mathrm{kPa}$ before to $54 \pm 6.6 \mathrm{kPa}$ at $5 \mathrm{~min}$. Later, a nonsignificant tendency toward a decrease was observed. $\mathrm{PaCO}_{2}$ decreased from 


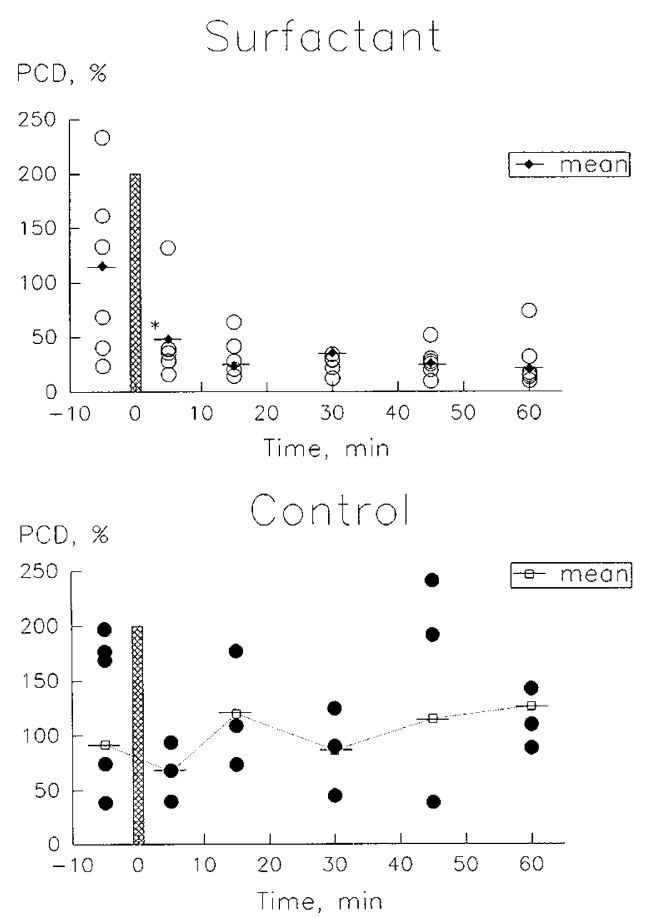

Fig. 4. PCD in the surfactant-treated group and in the control group. The hatched hars show the time of treatment. Individual and mean values are shown. In the treatment group, $F$ values (with $d f$ as subscripts) and $p$, obtained by two-way analysis of variance, were $3.7_{5}$ and 0.01 , respectively. There were no significant changes in the control group. *, Significant change in relation to preceding measurement $(p<0.05)$.

\section{Surfactant}

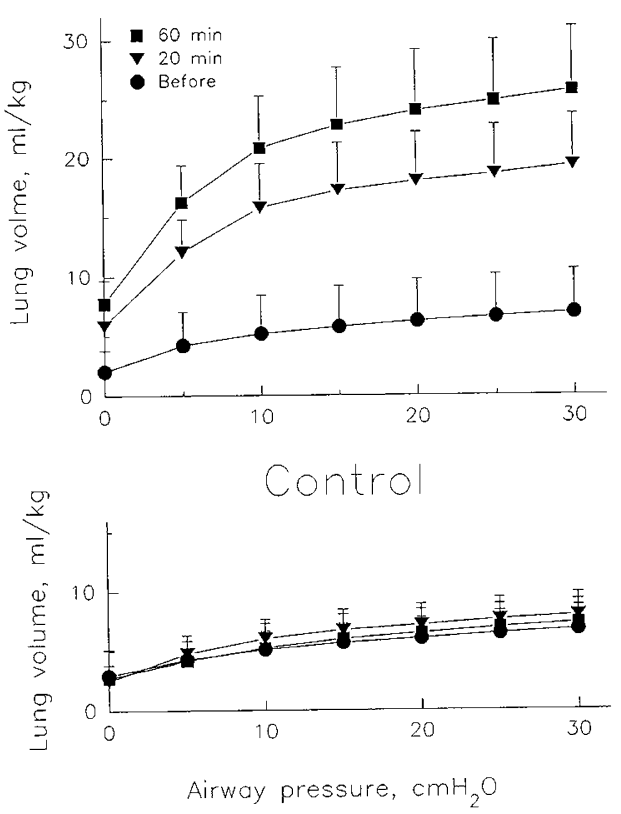

Fig. 5. Mean $(+\mathrm{SD}) \mathrm{P}-\mathrm{V}$ curves obtained in the surfactant-treated group and the control group. Measurements were taken before and at 20 and $60 \mathrm{~min}$ after endotracheal surfactant instillation.

$5 \mathrm{~min}$ before to $5 \mathrm{~min}$ after $(p<0.05)$, reflecting the increase in $\mathrm{V}_{\mathrm{T}}(p<0.05)$ (peak inspiratory pressure was held constant).

\section{DISCUSSION}

We studied lambs with a gestational age of $120-122 \mathrm{~d}$ that are
Table 2. Values (mean $\pm S D$ ) obtained before and at 20 and 60 min after surfactant instillation*

\begin{tabular}{cccc}
\hline & Before & $20 \mathrm{~min}$ & $60 \mathrm{~min}$ \\
\hline $\mathrm{V}_{0} /$ TLC & $0.29 \pm 0.12$ & $0.28 \pm 0.03$ & $0.28 \pm 0.08$ \\
$\mathrm{~V}_{5} /$ TLC & $0.56 \pm 0.09$ & $0.57 \pm 0.04$ & $0.58 \pm 0.07$ \\
$\mathrm{~V}_{10} /$ TLC & $0.67 \pm 0.07$ & $0.74 \pm 0.02$ & $0.74 \pm 0.02$ \\
$\mathrm{~V}_{20} /$ TLC & $0.81 \pm 0.03$ & $0.85 \pm 0.01$ & $0.086 \pm 0.01$ \\
$\mathrm{C}_{\text {dyn }} /$ TLC & $0.012 \pm 0.003$ & $0.010 \pm 0.001$ & $0.010 \pm 0.002$ \\
$\mathrm{C}_{\max } /$ TLC & $0.069 \pm 0.025$ & $0.077 \pm 0.021$ & $0.079 \pm 0.015$ \\
\hline
\end{tabular}

$* \mathrm{~V}_{0}, \mathrm{~V}_{5}, \mathrm{~V}_{10}$, and $\mathrm{V}_{20}$ are the lung volumes at $0,5,10$, and $20 \mathrm{~cm} \mathrm{H}_{2} \mathrm{O}$ of airway pressure, respectively. There were no significant changes.

known to exhibit a derangement of lung function similar to that of premature infants with RDS $(11,12)$. Although, in lambs, surfactant synthesis begins around $120 \mathrm{~d}$ gestational age, secretion to the alveoli first starts some days later (13). Older lambs do not consistently develop RDS, and Sandberg et al. (14), who studied lambs at $129-131$ gestational d, found that $30 \%$ had no histologic signs of RDS. In the present study, all animals had severe respiratory distress at the start of the experiment period (Table 1), and two control lambs died within $40 \mathrm{~min}$.

The bovine surfactant used in the present study has a good physiologic activity in other animal models (15-17). We used a greater dose $(150 \mathrm{mg} / \mathrm{kg})$ than is commonly used $(50 \mathrm{mg} / \mathrm{kg})$, which might have accentuated the effect.

The FRC measurement system has been found to be accurate and reproducible in model lungs and in animals with lung volumes down to $5 \mathrm{~mL}$ that were ventilated with $\mathrm{V}_{\mathrm{T}}$ down to 4 $\mathrm{mL}$ at respiratory rates up to $80 / \mathrm{min}$. It has been used with success in prematurely born neonates (body weights as low as $500 \mathrm{~g}$ ) with RDS (6). The system has the advantage of not interfering with ventilator settings or with inspired gas composition. However, it has the same limitations as other gas-dilution methods, i.e. the results will be erroneous in the presence of leaks, and it only measures lung units communicating with the large airways.

Occlusion during expiration has been used to characterize the passive mechanics of the respiratory system $(18,19)$. In these studies, multiple breaths were used to describe P-V relations inside the $\mathrm{V}_{\mathrm{T}}$. A variant of this technique, which uses multiple interruptions of the expiratory flow within one breath, has shown accurate results in animals $(10,20)$, in intubated adults $(21)$, and in infants (22). In the present study, the passive elastic properties of the respiratory system were measured during exhalation from maximum inflation. When using an interrupter technique, it is important to get a pressure plateau during the occlusion period to ascertain pressure equilibrium between the airway and alveoli and absence of gas leaks. The occlusion period in this study, 80 $\mathrm{ms}$, may seem short, but we could demonstrate a well-defined plateau at the end of each occlusion. Also, Carlo (20), who studied rabbits with healthy or surfactant-depleted lungs, found that a pressure equilibrium was reached within 50 to $100 \mathrm{~ms}$ after an occlusion.

Immediately after surfactant instillation, $\mathrm{PaO}_{2}, \mathrm{FRC}$, and dynamic and static compliance improved. In addition, gas distribution became more even and $\mathrm{PaCO}_{2}$ decreased markedly.

There was a fast initial increase in FRC (mean FRC at $5 \mathrm{~min}$ after surfactant instillation was $170 \%$ of the initial value) followed by a slower additional increase (Fig. 3). This and the simultaneous rise in compliance suggest that a momentary recruitment of peripheral airways occurred. This was also reflected in the rapid increase in $\mathrm{PaO}_{2}$. However, individual variations in the FRC response were noted; in four of the six surfactant-treated lambs, the major increase occurred within $5 \mathrm{~min}$ and in the two others the effect was somewhat delayed. An explanation for this variability could be that the lambs had different amounts of fluid left in the lung, i.e. the dilution of the surfactant varied between the animals. The small, gradual increase in FRC after the initial phase could be explained by a resorption or redistribution of the 
alveolar fluid into the interstitial and intravascular compartment (23). An overdistension of peripheral airways is less likely because an alveolar overdistension would have decreased compliance and made gas distribution more uneven (24), i.e. resulted in effects opposite of those that we observed.

In contrast to the present study, studies in mechanically ventilated premature neonates have not demonstrated any improvement in $C_{d y n}$ after surfactant instillation $(1,2)$. However, $C_{d y n}$ is not in these circumstances a suitable measure of static properties on the lungs and thorax because it also depends on the lung volume, PEEP level, $V_{T}$, and airway resistance. In the present study, the maximal compliance $\left(\mathrm{C}_{\max }\right)$, i.e. the maximal slope of the P-V curve, occurred at airway pressures below $5 \mathrm{~cm} \mathrm{H} \mathrm{H}_{2} \mathrm{O}$. This indicates that, if PEEP is kept above $5 \mathrm{~cm} \mathrm{H}_{2} \mathrm{O}$, the lung would operate on the flat upper part of the P-V curve during the $\mathrm{V}_{\mathrm{T}}$ and $\mathrm{C}_{\mathrm{dyn}}$ would remain low.

The decrease in PCD after surfactant instillation confirms the results by Sandberg et al. (14) and shows that the gas distribution became more even. We think that the finding is due to a stabilization of distal airways by surfactant.

$\mathrm{PaO}_{2}$ increased immediately after surfactant instillation. The increase was higher than what other authors have found after surfactant treatment in lambs of similar age $(12,25,26)$. One explanation might be the larger dose of surfactant used in our study $(150 \mathrm{mg} / \mathrm{kg})$. The early positive effect on oxygenation tended to weaken after about $10 \mathrm{~min}$, which is consistent with other studies $(12,25)$.

We conclude that endotracheal surfactant improved lung volumes, gas distribution, compliance, and oxygenation and that the main changes took place within 5 to $20 \mathrm{~min}$. There was no significant change in TLC normalized values for lung volumes at various inflation pressures or in specific compliance, i.e. the basic shape of the P-V curve was little affected by surfactant instillation. This indicates that the increase in communicating gas volume was caused by a momentary recruitment and stabilization of peripheral airways, rather than overdistension of already aerated lung regions. The subsequent additional recruitment of lung volume may have been caused by clearance of lung liquid.

Acknowledgments. The authors thank Janne Persson and Ari Kok for their valuable technical assistance.

\section{REFERENCES}

1. Davis JM, Veness-Meehan K, Notter RH, Bhutani VK, Kendig JW, Shapiro DL 1988 Changes in pulmonary mechanics after the administration of surfactant to infants with respiratory distress syndrome. N Engl J Med 319:476-479

2. Couser RJ, Ferrara TB, Ebert JE, Hoekstra RE, Fangman JJ 1990 Effects of exogenous surfactant therapy on dynamic compliance during mechanical breathing in preterm infants with hyaline membrane disease. $J$ Pediatr 116:119-124

3. Metcalfe IL, Enhorning G, Possmayer F 1980 Pulmonary surfactant-associated proteins: their role in the expression of surface activity. J Appl Physiol 49:3441

4. Larsson A, Jonmarker C, Werner O 1988 Ventilation inhomogeneity during controlled ventilation. Which index should be used? J Appl Physiol 65:20302039

5. Larsson A, Jonmarker C, Lindahl SGE, Werner O 1989 Lung function in the supine and lateral decubitus positions in anaesthetized infants and children. Br J Anaesth 62:378-384

6. Vilstrup CT, Björklund LJ, Larsson A, Lachmann B, Werner O 1992 Functional residual capacity and ventilation homogeneity in mechanically ventilated small neonates. J Appl Physiol 73:276-286

7. Jonmarker C, Castor R, Drefeldt B, Werner O 1985 An analyzer for in-line measurement of expiratory sulfur hexafluoricie concentration. Anesthesiology 63:84-88

8. Fowler WS, Cornish Jr ER, Kety SS 1952 Lung function studies. VIII. Analysis of alveolar ventilation by pulmonary $\mathrm{N}_{2}$ clearance curves. J Clin Invest $31: 40-50$

9. Bouhuys A, Jönsson R, Lundin G 1958 Non-uniformity of pulmonary ventilation in chronic diffuse obstructive disease. Acta Med Scand CLXII:29-46

10. Gottfried SB, Rossi A, Calverley PMA, Zocchi L, Milic-Emili J 1984 Interrupter technique for measurement of respiratory mechanics in anesthetized cats. J Appl Physiol 56:681-690

11. Stahlman M, LeQuire VS, Young WC, Merrill RE, Birmingham RT, Payne GA, Gray J 1964 Pathophysiology of respiratory distress in newborn lambs. Am J Dis Child 108:375-393

12. Jobe A, Ikegami M, Glatz T, Yoshida Y, Diakomanoli ES, Padbury J 1981 Duration and characteristics of treatment of premature lambs with natural surfactant. J Clin Invest 67:370-375

13. Brody JS, Thurlbeck WM 1986 Development, growth, and aging of the lung. In: Geiger SR, Macklem PT, Mead J, Fishman AP (eds) Handbook of Physiology, Vol 3, Mechanics of Breathing, Part 1. American Physiological Society, Bethesda, MD, pp 355-386

14. Sandberg K, Edberg K-E, Benton W, Silverberg A, Sladek M, Sundell HW 1991 Surfactant improves gas mixing and alveolar ventilation in preterm lambs. Pediatr Res 30:181-189

15. van Daal G-J, So KL, Gommers D, Eijking EP, Fiévez RB, Sprenger MJ, van Dam DW, Lachmann B 1991 Intratracheal surfactant administration restores gas exchange in experimental adult respiratory distress syndrome associated with viral pneumonia. Anesth Analg 72:589-595

16. van Daal G-J, Bos JAH, Eijking EP, Gommers D, Hannappel E, Lachmann B 1992 Surfactant replacement therapy improves pulmonary mechanics in end-stage influenza A pneumonia in mice. Am Rev Respir Dis 145:859-863

17. Eijking EP, van Daal G-J, Tenbrinck R, Luijendijk A, Sluiters JF, Hannappel E, Lachmann B 1991 Effect of surfactant replacement on pneumocystis carinii pneumonia in rats. Intensive Care Med 17:475-478

18. Olinsky A, Bryan AC, Bryan MH 1976 A simple method of measuring total respiratory system compliance in newborn infants. S Afr Med J 50:128-130

19. Mortola JP, Fisher JT, Smith B, Fox G, Weeks S 1982 Dynamics of breathing in infants. J Appl Physiol 52:1209-1215

20. Carlo WA 1988 Validation of the interrupter technique in normal and surfactant deficient lungs. In: Bhutani VK, Shaffer TH, Vidyasagar D (eds) Neonatal Pulmonary Function Testing: Physiological, Technical and Clinical considerations. Perinatology Press, New York, pp 35-45

21. Gottfried SB, Rossi A, Higgs BD, Calverley PMA, Zocchi L, Bozic C, MilicEmili J 1985 Noninvasive determination of respiratory system mechanics during mechanical ventilation for acute respiratory failure. Am Rev Respir Dis 131:414-420

22. Sly PS, Brown KA, Bates JHT, Spier S, Milic-Emili J 1988 Noninvasive determination of respiratory mechanics during mechanical ventilation of neonates: a review of current and future techniques. Pediatr Pulmonol 4:39-
47

23. Jackson JC, Mackenzie AP, Chi EY, Standaert TA, Truog WE, Hodson WA 1990 Mechanisms for reduced total lung capacity at birth and during hyaline membrane disease in premature newborn monkeys. Am Rev Respir Dis 142:413-419

24. Goldsmith LS, Greenspan JS, Rubenstein D, Wolfson MR, Shaffer TH 1991 Immediate improvement in lung volume after exogenous surfactant: alveolar recruitment versus increased distension. J Pediatr 119:424-428

25. Jacobs H, Jobe A, Ikegami M, Glatz T, Jones SJ, Barajas L 1982 Premature lambs rescued from respiratory failure with natural surfactant: clinical and biophysical correlates. Pediatr Res 16:424-429

26. Jobe A, Jacobs H, Ikegami M, Berry D 1985 Lung protein leaks in ventilated lambs: effect of gestational age. J Appl Physiol 58:1246-125 